\title{
NSIS COUNCIL
}

\section{Reports from the Annual General Meeting, May 2015}

\author{
AGENDA \\ $154^{\text {TH }}$ ANNUAL GENERAL MEETING \\ 5 pm - 4 May 2015 \\ The Great Hall, University Club \\ Dalhousie University, Halifax, NS
}

1. Minutes of $153^{\text {rd }}$ AGM, 2014

2. President's Annual Report (Pat Ryall)

3. Treasurer's Annual Report (Angelica Silva)

4. Editor's Annual Report (Peter Wells)

5. Librarian's Annual Report (Michelle Paon)

6. Lecture Programme for 2015-2016 (Jason Clyburne)

7. Proposed Excursions for 2015-2016 (Hank Bird)

8. Science Writing Competition Annual Report (Hank Bird)

9. Change to By-law 11 regarding Membership Fees

10. NSIS Sponsorship of local scientific events

11. Nominating Committee for 2015-2016 (Pat Ryall)

12. Any Other Business

13. Adjournment 


\title{
NOVA SCOTIAN INSTITUTE OF SCIENCE
}

\section{MINUTES OF THE $153^{\text {RD }}$ ANNUAL GENERAL MEETING}

\author{
5 May, 2014 \\ Dalhousie University Faculty Club
}

Council Members present: Tom Rand (President), Patrick Ryall (Vice-President), Michelle Paon (Past President and Librarian), Angelica Silva(Treasurer), Linda Marks (Secretary), Peter Wells (Editor), Henry Bird (Writing Contest Coordinator), John Young, Richard Singer

Members present: Stuart Grossert, David Richardson, Chris Corkett, Robert Cook, Eric Mills, Ann Mills, Judy Bird, Carol Morrison, David Richey, Matthew Richey, Gareth Harding

Others present: Laura Bennet (Nova Scotia Museum Representative nominee)

Regrets (Council Members): Suzuette Soomai (Webmaster), LeighAnn Bishop (Science Teacher's Representative), Allison Chua (Student Representative)

The President welcomed members and called to order the 153rd Annual General Meeting (AGM). It was noted that the reports, excluding the minutes from last year`s AGM, would be passed, as a unit, at the end of the presentations.

\section{Approval of the Minutes of the 152nd Annual General Meeting of 6th May, 2013}

Motion to accept the minutes:

MOVED: Michelle Paon

Seconded: Henry Bird

Richard Singer noted that his regrets, for not attending the 2013 AGM, had not been recorded. No additional discussion. All in favour. Carried 


\section{President's Annual Report (Tom Rand):}

Tom Rand presented the President's Report (attachment \# 1) and thanked Council for its support during his tenure. The President noted that he looked forward to continuing to work with the Institute and help it fulfill its goals, especially in fostering and promoting Science in Nova Scotia and supporting the dissemination of peer-reviewed scientific research.

\section{Public Lectures:}

The President reported that the Institute had another successful lecture series. In addition to the President the Lecture Committee consisted of Michelle Paon, Kevin Hewitt, and John Young. The lectures focused on the general theme of energy. The President thanked all of the speakers and the Nova Scotia Museum of Natural History, especially Jeff Gray and Robin Gilliam, for enabling the NSIS to use their conference room and auditorium.

The NSIS co-sponsored several conferences and lectures:

October 2013. A public lecture by Dr. Philip Kitcher, the John Dewey Professor of Philosophy, at Columbia University entitled "Can we Sustain Democracy and the Planet too?"

November 2013. Ninth Annual Public Sable Island workshop

November 2013. "A Changing Sea" by Dr. Scott Doney from the Woods Hole Oceanographic Institute and this year's Huntsman Award winner.

June 2014. Maury Conference on the History of Oceanography. The upcoming conference will honour the life and work of eminent oceanographer and NSIS member, Dr. Eric Mills.

\section{Student Support:}

The President reported on several initiatives aimed at students:

- The annual Student Science Writing Competition, which is open to Nova Scotian university students. The President thanked Hank Bird for coordinating the contest; acknowledged the financial support from Situating Science Strategic Knowledge Cluster-Atlantic Node; and congratulated the winners. 
- Financial support to 10 Regional Science Fairs in the form of $\$ 150.00$ in prize money to each.

- Financial support to a graduate student poster competition at the annual conference of the Fishermen and Scientists Research Society in February 2014

- Financial support to RobotsEastAtlantic Championship for school children in May 2014

\section{Members:}

On a sad note, the President reported that Dr. Robert G. Ackman passed away in July 2013. Dr. Ackman was a long-time NSIS member, President of the Institute from 1973 to 1974 and also served as a member of the Editorial Board for the Proceedings of the Nova Scotia Institute of Science.

\section{Finances:}

The President noted that the Institute's finances were secure, in part due, to a bequest of $\$ 15,000$ made by the late Dr. Alan Taylor to the "Library of the Nova Scotian Institute of Science, Halifax, Nova Scotia to be used for maintenance and expansion". Over the past year Council members have discussed meaningful ways in which the funds can be used. Dr. Taylor was a Past Editor of the Proceedings and a Life Member. In April 2014 the Institute also received \$1000 from the Minster of Communities, Culture and Heritage to support the continued publication of the Proceedings of the Nova Scotian Institute of Science.

\section{Support to Basic Science:}

The President reported that in the past year Council continued to support the Institute's goals of fostering and promoting Science in Nova Scotia and the dissemination of peer-reviewed scientific research. Letters were sent to the Federal Minister(s) of Fisheries and Oceans, outlining our grave concerns about limits being placed on federally employed scientists to communicate the results of their research. Council also discussed ways in which the NSIS can support Peter Well's editorial (Vol. 47(2) 2013) which called for support to basic science in the region and encouraged evidence-based public policy on issues impacting on science in Canada. The President reported that in November 2013 he and Ron MacKay attended a public meeting at 
the Art Gallery of Nova Scotia which discussed various strategies that could be employed to promote science in the region. (All the above measures provided continued support to a motion made at the $151 \mathrm{st}$ Annual General Meeting of May 2012).

\section{Membership:}

The President reported that in February 2014 a committee was struck to look at ways to increase NSIS membership and also increase its involvement in promoting science in the region. In addition to the President, the Committee consisted of John Young, Kevin Hewitt, Pat Ryall and Kara McPhee. The Committee reaffirmed that the Institute should continue its sponsorship of, and representation at, various public science-based conferences, meetings, open houses, and lectures. The Institute should also continue to support the science fairs and other student competitions such as RobotsEAST and the Fishermen and Scientists Research Society's graduate poster contest. The Committee discussed the need for a Publicity Officer; outreach activities such as excursions and representation at Atlantic Science Teachers retreats. Other initiatives discussed included benefits associated with holding a NSIS membership card and updated methods to collect membership dues such as credit card payments. The President hopes to prepare a white paper on the work of the Committee by the fall 2014 .

The President thanked Council and the membership for their assistance and extended a special thank-you to Michelle Paon for her leadership and assistance during his tenure. The President acknowledged and thanked the two members of Council who will retire this spring; Secretary Linda Marks and Student Representative Allison Chua.

\section{Treasurer's Annual Report (Angelica Silva)}

Angelica Silva presented the Treasurer's report (attachment \# 3) and reported that the Institute is financially secure with assets of $\$ 69,129.24$. The Treasurer was pleased to report that the NSIS has received a generous bequest of $\$ 15,000$ from the late Dr. Alan Taylor. This bequest will be a legacy fund towards the maintenance and expansion of the NSIS library and the communication of science within Nova Scotia. Dr Taylor was a Past Editor of the Proceedings and a Life Member of the Institute.

Expenses included the publication of the Proceedings, promotion and presentation of the lectures, the Institute`s website and student 
prizes. Other expenses included contributions to special public lectures. Revenue included the sale of the Proceedings, a payment from Access Copyright, and membership dues.

The Institute currently has 108 individual members, including 8 life members and 4 student members. The Treasurer reported that the Institute has had little success attracting student members.

\section{Discussion:}

Michelle Paon noted that the reported expenses for production of posters and pamphlets should be $\$ 630$ not $\$ 230$. The Treasurer will check to see if some of the expenses relate to the AGM. This year`s 2014 AGM expenses will be reported at the 2015 meeting.

Carol Morrison noted that federal regulations govern the amount of money that organizations such as the NSIS can accumulate. It was felt that the Institute was well within the regulated limit.

David Richardson (a past President of the NSIS) commented that membership dues cover much of the Institute`s yearly expenses and that investments are generally used, as required, for special projects.

\section{Editor's Annual Report (Peter Wells/Associate Editor, D. Richardson)}

Peter Wells presented the Editor's report (attachment \# 3):

Volume 47 (Part2) of the Proceedings of the Nova Scotian Institute of Science was published in January 2014. This issue contained an editorial, six papers on a variety of topics and the Institute's 2013 reports from Council.

The Editor reported that two papers are being considered and additional papers sought for the next issue of the Proceedings. One of the papers being considered is an invited paper by Dr. Suzanne Zeller of Wilfred Laurier University on the 150 year history of the NSIS. A special issue on Bay of Fundy science is being planned and will consist of papers resulting from the upcoming Bay of Fundy Ecosystem Partnership Workshop at the Coastal Zone Canada Conference in June 2014.

A revised Guide to Authors is being prepared to aid the preparation of papers for the Proceedings. Preparations are moving ahead to have future issues of the Proceedings produced in an electronic format which will be available exclusively to members for six months. After six months the issue will be "open access". The Editor acknowledged the work and support of many people in these endeavors. 
A display to promote the NSIS and its publications is planned for the upcoming Coastal Zone Canada Conference and for the Maury History of Marine Science Conference.

The Editor welcomed suggestions to improve the Proceedings, its role in the Institute, and its continued contribution to science in Nova Scotia and beyond. The Editor also expressed his appreciation to authors and to the Editorial Board for their contributions to the Institute.

\section{Librarian's Annual Report (Michelle Paon)}

Michelle Paon reported highlights of the Librarian's report (attachment \# 4):

The Librarian acknowledged her colleagues at Dalhousie University's Killiam Library for their contributions to the maintenance of the Institute's journal collection and whose efforts enable on-line access to the Proceedings of the Nova Scotian Institute of Science.

With the digitization of volumes 37- 41 the DalSpace repository contains Vol. 1 (1863) to Vol. 41 (2001) of the Proceedings. http:// dalspace.library.dal.ca/handle/10222/11192

The Librarian reported Proceedings layout editor Gail LeBlanc has converted articles from the Proceedings (2002-2013) to portable document format (pdf) and the articles have been uploaded to the Open Journal System (OJS). The OJS will serve as the production platform for forthcoming issues of the journal. The website now provides online access to issues of the Proceedings from Vol. 42 (2002) to Vol. 47 (2013): http://ojs.library.dal.ca/nsis. For the first six months following the publication of the most recent issue of the Proceedings, access will be available only to NSIS members, through the use of a username and password which can be obtained by emailing Carol Richardson (clrichar@dal.ca).

There are currently 19 Institutional members and 87 NSIS Exchange Partners. Institutional members and Exchange Partners have been notified that future issues of the Proceedings will be available online and provided information that will allow them to access the most recent issue of the Journal via a username and password or their internet protocol (IP) address.

The Librarian reported that forms were submitted to Access Copyright for the 2013 repertoire payment given to publishers. The Institute received a payment of $\$ 803.56$.

NSIS continues to receive publications from exchange partners around the world. These journals are from a wide variety of scientific 
disciplines and are available in several languages. The Librarian thanked Carol Richardson and the Serials Department staff in the Killam Library who process and make available the journals.

\section{Nominating Committee for 2014-2015 Report (Michelle Paon)}

Committee Chair Michelle Paon presented the nominations (attachment \#5) for the 2014-2015 Council on behalf of the Committee which included Tom Rand and John Young, in addition to the Chair.

Michelle Paon thanked those members who will continue to serve on the 2014-2015 Council and those who have volunteered to serve in new positions.

There were three calls for additional nominations from the floor. As there was "no contest" to the proposed slate of officers it was declared that the nominations be elected by acclimation.

New members to Council are Jason Clyburne (Vice-President), Kelly Krashinsky (Secretary), Zoe Kirste (Student Representative) and Laura Bennet (Nova Scotia Museum Representative).

Michelle Paon congratulated the new team.

\section{Lecture Programme for 2013-2014 (Patrick Ryall)}

Lecture Committee Chair Patrick Ryall presented the lectures for 2014-2015 (attachment \#6) and thanked committee members Michelle Paon, Tom Rand, Ron MacKay, John Young and Carol Morrison for their work.

The theme of the 2014-2015 lecture series will be "People and the Earth". The eight lectures will cover a variety of topics describing how people have been affected by the Earth, and how people have been changing the Earth.

One lecture will take place, outside metro, at the Irving Centre, Acadia University in Wolfville.

\section{Student Writing Contest (Henry Bird) - addition to agenda}

Henry Bird (attachment \#7) reported that thirteen students (4 undergraduate and 9 graduate) submitted manuscripts to the 2014 Competition. Two Honourable Mentions were awarded in the Undergraduate category and one Prize and one Honourable Mention were awarded in the Graduate category.

This year Hank Bird, Stuart Grossert, Tom Rand, David Richardson, John Rutherford, and Pat Ryall served as judges. 
Henry Bird acknowledged the continuing support of Situating Science Knowledge Cluster to the Writing Contest.

Tom Rand asked for a motion to accept all the Reports: MOVED: Michelle Paon

Seconded: David Richardson

All in favour. Carried

\section{Other Business:}

Publicity Officer: The general duties of Publicity officer were outlined and include the design of the NSIS brochures and the promotion of the Institute's activities in metro and around the province. A request was made for a volunteer to fill this position. David Richardson suggested that if members have any nominations or suggestions that they contact Tom Rand.

David Richardson noted his appreciation to Librarian Michelle Paon and all others involved in making back issues of the Proceedings of the NSIS available on-line.

Michelle Paon thanked outgoing President, Tom Rand, for his efforts on behalf of the Institute and noted that each new President brings something new to the position.

\section{Adjournment: Moved: at 6:05 pm by Tom Rand}

Respectfully submitted:

Linda Marks

Secretary 


\section{REPORTS FROM THE NSIS COUNCIL NOVA SCOTIAN INSTITUTE OF SCIENCE \\ PRESIDENT'S REPORT: 2014 TO 2015}

I would like to take this opportunity to thank Council members for their helpful collaboration during the past year - you've been a great group to work with, and thank you for putting up with me.

\section{Public Lectures}

This year's lecture series was based on interactions between people and the Earth ranging from natural events such as earthquakes to phenomena such as sea-level rise and soil productivity due to human induced climate change. Since this is the Nova Scotian Institute of Science, we decided to have one of our talks at the Irving Centre at Acadia University in Wolfville. This was well attended with over a hundred people. Another unusual happening was having to cancel our February talk due to extreme snow. The replacement talk was held at the Alderney Gate library in Dartmouth with about 90 people in attendance, and some people turned away. We are planning to have a lecture at Acadia in the coming session.

Thanks to the organizing committee that put this series together (Carol Morrison, Ron MacKay, Michelle Paon, Tom Rand, John Young and myself).

\section{Sponsorships}

NSIS provided support for three conferences since our last AGM:

\section{The Maury Conference on the History of Oceanography}

The NSIS provided financial and organizational support for this conference held on June $14^{\text {th }}$ and $15^{\text {th }}$ at Kings College, which honoured Dr. Eric Mills.

\section{Coastal Zone Canada Conference and Bay of Fundy Workshop}

The NSIS provided financial support for this conference which was held at the World Trade and Convention Centre in Halifax from June $15^{\text {th }}-19^{\text {th }}, 2014$. 


\section{Sable Island Conference 2015 - The Science and History of Sable Island}

The NSIS provided financial support and was involved in organizing the conference. Two of us (Ryall \& Wells) were on the programme committee. It is expected that several of the conference presenters will be submitting papers to the Proceedings of NSIS.

\section{Nova Scotia Regional Science fairs}

NSIS continues to support 10 Regional Science fairs by giving a $\$ 150$ prize for each fair.

\section{Student Science Writing Competition}

I'd like to thank Hank Bird for continuing to organize this competition - I'll leave it up to him to talk about the results.

\section{Excursions}

We have not had any excursions in the past year, but we did establish a committee (Hank Bird, Zoe Kirste, Michelle Paon, Pat Ryall and Peter Wells) which prepared a list of possible excursions for circulation to the membership in order to determine their preferences and which ones should be organized.

\section{Dr. Alan Taylor's bequest}

Dr. Alan Taylor left a bequest of $\$ 15,000$ for the NSIS library. Council has had extensive discussions on what to spend this money on and over what period of time. We considered using this money to get popular scientific books into public libraries in the province and we did get approval from Dr. Taylor's estate. We have put $\$ 10,000$ into a one-year investment. Laura Bennett is working with the provincial library system to determine how they would spend $\$ 5,000$. The books purchased for the public libraries would have a stamp recognizing NSIS and Dr. Taylor's contribution.

\section{The Future}

The NSIS continues to be financially secure, but we are in a time when much is changing. We have a greying membership and need to reach out and get more young people involved. We are proposing to revise Membership By-law (item 9 of the Agenda) $n$ order to clarify the time of membership and provide a membership card which will allow us to develop exchange programs with other organizations. I'm pleased to 
say we have two young women, Zoe Kirste and Nicole LeBlanc, who are going to work together as Publicity Officers to reach out through the evolving social media to a broader audience. I would like to take this opportunity to thank Michelle Paon who, while officially being our Librarian, has worked above and beyond the call of duty by looking after publicity by preparing and distributing our lecture brochures and posters, as well as contacting the media.

Finally, thanks again to all Council members, it has been a pleasure working with you and I look forward to continuing our work in the future as we seek to expand NSIS's outreach.

Respectfully submitted:

Patrick Ryall, President 


\section{TREASURER'S REPORT}

\section{NOVA SCOTIAN INSTITUTE OF SCIENCE \\ Year End 2014-2015 \\ March 31, 2015}

\section{ASSETS:}

Bank Account BMO (as of March 31, 2015)

Investments (value on February 28, 2014)

TOTAL ASSETS:

$\$ 70,196.23$

\section{LIABILITIES AND NET WORTH}

Accounts Payable

NET WORTH

TOTAL LIABILITIES AND NET WORTH

\$ 70,196.23

INVESTMENTS (as of March 31, 2014)

Renaissance High Interest Savings Account

(March 31, 2015)@1.0\%

$15,094.82$

Manulife Bank Investment Certificate @2.45 \%

due February 1, 2018

$21,000.00$

Equitable Trust Company GTD investment @ 2.15\% due May 16, 2017

HomeTrust CO GTD investment @ 1.9\% due October 22, 2015

HomeTrust CO GTD investment @ 2.1\% due July 15, 2016

Interest - cash and cash equivalent 


\section{NSIS AGM 2014-2015}

\section{Finances}

The net worth of NSIS is $\$ 70,196.23$ as of March 31, 2015. For this 2014-2015 period, NSIS received a Nova Scotia Province Eduaction Grant for $\$ 1000$ and publication royalties for a total of $\$ 642.37$ from ACCESS copyright. Other income was received from NSIS memberships for \$2,890 (regular, students and LIFE); Institutional memberships for $\$ 420$, sales of NSIS Proceedings, Flora of Nova Scotia and Birds of Brier Island publications, AGM dinner registrations for $\$ 1,440$; Donations for $\$ 170$. A total Income of $\$ 7,878.90$

Total expenditures for contributions to special lectures, writing competition contest and prizes were $\$ 3,750$, these included $\$ 500.00$ for Michael Butler the graduate student winner of the 2014 NSIS writing competition; \$1,500 for ten Regional Science Fairs (includes 2014 and 2015, two have not yet cashed cheques); a contribution for CZC 2014 of \$ 750; a contribution to Maury Conference of Oceanography of \$ 500 and a contribution of $\$ 500$ to Robots East. Other expenditures did include cost of mailing proceedings to members and to exchange institutions for $\$ 1,326.82$; AGM expenditures $\$ 1,874.44$ (AGM dinner, gifts to AGM speaker, NSIS recognition to NSIS Secretary); Museum (MNHNS) and Library (Alderney) rental \$234.50; cost printing of NSIS 2014-2015 Brochures and monhtly posters $\$ 707.25(\$ 655.50+\$ 51.75)$; office supplies and postage membership \$ $141.73(\$ 27.89+113.84)$; plus cost of BMO history for $\$ 5$. Total expenditures of $\$ 8,039.74$.

\section{NSIS Membership}

The NSIS has 104 members and includes 74 regular members, 9 Life Members, 4 Students and plus 17 Institutional Members. Dues from Individual members were $\$ 2,890$ plus $\$ 420$ from institutional members.

Respectfully submitted to

NSIS AGM 2014-2015 on May 4th, 2015

Angelica Silva

NSIS Treasurer

Halifax, Nova Scotia. 
NOVA SCOTIAN INSTITUTE OF SCIENCE

REVENUES AND EXPENDITURES 2014- 2015

NSIS AGM 2014-2015

REVENUE as of March 31, 2015

Membership Dues

Regular, students LIFE and institutions $\$ 3,310.00$

AGM dinner (2014) (May 2014) $\quad 1,440.00$

Sales NSIS Proceedings, Birds of Brier Island, Flora NS 1,316.50

Nova Scotia Grant $\quad 1,000.00$

$\begin{array}{ll}\text { Donations } & 170.00\end{array}$

Income/Royalties Access copyright Royalty $\quad 642.37$

$\begin{array}{ll}\text { BMO Bank Interest } & 0.06\end{array}$

TOTAL REVENUE $\$ \$ \mathbf{8 7 8 . 9 3}$

EXPENSES as of March 31, 2015

Advertisement

(print NSIS brochures, lecture posters)

$\$ 707.25$

AGM (2014) (dinner, lecturer accomod)

$1,874.44$

Mail PNSIS (SMU, DAL)

$1,326.82$

Lecture Sponsorship, NSIS Writing, Science Fairs

$3,750.00$

Rent MNHNS and Alderney Library

234.50

Supplies office, postage (membership, CRA) 141.73

Bank cost (printing of History)

TOTAL EXPENSES

$\$ 8,039.74$

Expenses over income 2013-2014 


\section{EDITOR'S REPORT}

\section{NSIS ANNUAL GENERAL MEETING \\ May 2015}

PNSIS Volume 48(1) 2015 was published in March 2015. It has two major invited papers, one of which by Dr. Suzanne Zeller covers the history of the Society over the past 150 years, and two contributed papers by NSIS members. A printed copy is available for members and for sale, as well as the Issue being on the website. The Issue is open access after six months. All members of the Editorial Board are thanked for their work on this Issue, as well as members of the Killam Library and Suzuette Soomai (Webmaster) for assistance with electronic storage through DalSpace and the website. Lastly, we thank the authors for their contributions.

PNSIS Volume 48 (2) 2015 is being organized now. A number of submissions have been received and are being considered. Additional papers are being solicited from the speakers at the monthly meetings. PNSIS reports on the monthly meetings, where talks are given, as well as being a repository for papers on Maritime science. We need more papers, long or short, on these talks as they are an excellent crosssection of regional science.

A special issue of PNSIS (Vol. 49 (1)) from the Sable Island Conference, held in Halifax on May $1-2^{\text {nd }}$, is being planned. Editor's note: Papers were placed into PNSIS Vol 48(2) 2016. NSIS is a co-sponsor of the Conference with the Friends of Sable Island and the School of Resource and Environmental Studies (Dalhousie Univ.). This issue will be co-edited with Dr. Martin Willison (Dalhousie Univ.).

Members of NSIS and scientists across the region are encouraged to submit papers based on their original research or expert knowledge of Maritime science. Review papers and viewpoints are also welcome for future issues.

Respectfully submitted by:

P.G. Wells, Dalhousie University, Editor D. H. S. Richardson, Saint Mary's University, Associate Editor April 30 $0^{\text {th }} 2015$. 


\section{LIBRARIAN'S REPORT 2014/2015}

\section{Prepared for AGM May 4, 2015}

It has been a pleasure to serve as the NSIS Librarian during the past year. In this role, I oversee the receipt of journals from NSIS exchange partners around the world. I also work with Killam Library staff members who prepare these journals for the shelves and facilitate access to the online Proceedings of the Nova Scotian Institute of Science.

\section{Proceedings of the Nova Scotian Institute of Science}

The Open Journal Systems (OJS) software now serves as the online publication platform for new issues of the Proceedings. In April, production editor Gail LeBlanc loaded volume 48(1) to its online site at: https://ojs.library.dal.ca/nsis/issue/view/566. Thanks go to Dalhousie Libraries' staff member Susan Harris who provided assistance with technical issues.

\section{Institutional Members and Exchange Partners}

Renewal notices were sent to institutional members in February 2015. There are currently 17 institutional members (two less than last year), ten of which have submitted their internet protocol (IP) addresses to NSIS. There are currently 85 NSIS exchange partners (two less than last year) seventeen of which have submitted their IP addresses. All members, exchange partners and the general public have access to the online back issues of the Proceedings, as long as the issues have been published more than six months ago. (One exception is the special issue Birds of Brier Island, which NSIS has not made available online.)

\section{Sales of the Proceedings of the Nova Scotian Institute of Science} During 2014/2015, sales of the Proceedings generated $\$ 1080.00$ in revenue. Please see Appendix A (attached) for details. Of note, during the summer, 17 copies of the Flora of Nova Scotia were sold, and during the year, 18 copies of the Birds of Brier Island were sold. In October 2015, the NSIS Librarian arranged to place several copies of Birds of Brier Island on consignment at Bookmark bookstore (Spring Garden Rd.) and Atlantic News (Morris St.) to potentially benefit from exposure in these locations. To date only three issues of the book have been sold in these locations, but the retailers are willing to continue 
the arrangement during the upcoming summer. Money from the sale of the issues will be collected at the end of the consignment period.

\section{Access Copyright}

The NSIS Librarian submitted the required forms to Access Copyright for the 2014 repertoire payment to publishers. NSIS subsequently received a payment of $\$ 642.37$.

\section{NSIS Exchange Journal Collection}

A number of publications in the NSIS exchange collection have become very brittle and are in poor physical condition. Generally, these journal issues date from the late $19^{\text {th }}$ and early $20^{\text {th }}$ centuries and in many cases, they are in non-English languages. Fortunately, some of the journals are available free online. Considering their fragile physical state and space limitations in the library, NSIS Council has approved a project to identify potential candidates for discard. This initiative was started a few years ago by past NSIS Librarian Sharon Longard, and it will continue this year. It is expected that the limited number of patrons who seek this material will be better served by good quality online formats.

NSIS continues to receive journal issues from exchange partners around the world. As an example, from May 2014 to March of this year, 114 journal issues were delivered to the Killam Library from the Institute's exchange partners. These items have been processed and added to the NSIS collection in the Killam Library. On behalf of NSIS, I would like to thank Carol Richardson and the Serials Department staff in the Killam Library who process the exchange journals and make them shelf-ready. 
Appendix A: Sales of Proceedings - May 2014 - April 2015

\begin{tabular}{lcccr}
\hline Date & $\begin{array}{c}\text { Volume/Issue of } \\
\text { Proceedings of the } \\
\text { Nova Scotian Institute } \\
\text { of Science }\end{array}$ & \# Sold & Price & $\begin{array}{r}\text { Amount } \\
\text { Received } \\
(\$)\end{array}$ \\
\hline June 2014 & Birds of Brier Island & 2 & $\$ 20.00$ & $\$ 40.00$ \\
June / July 2014 & Flora of Nova Scotia & 15 & $\$ 35.00$ & $\$ 525.00$ \\
July 2014 & Birds of Brier Island & 15 & $\$ 25.00$ & $\$ 375.00$ \\
July 2014 & Flora of Nova Scotia & 2 & $\$ 35.00$ & $\$ 70.00$ \\
October 2014 & Birds of Brier Island & 1 & $\$ 25.00+\$ 10.00 \mathrm{~S} / \mathrm{H}$ & $\$ 35.00$ \\
December 2014 & Flora of Nova Scotia & 1 & $\$ 35.00$ & $\$ 35.00$ \\
Total & & $\mathbf{3 6}$ & & $\$ \mathbf{1 0 8 0 . 0 0}$ \\
\hline
\end{tabular}

Respectfully submitted by:

Michelle Paon

NSIS Librarian

May 4, 2015 


\section{PROPOSED NEW BY-LAW PERTAINING TO MEMBERSHIP FEES}

\section{Current NSIS by-law, from May 05, 2008}

11. The fees for ordinary, life, student, and institutional member, which will include payment for publications, shall be proposed by Council to the members, in writing, at least fourteen (14) days prior to the Annual General Meeting for approval by a majority vote of the members present at the Annual General Meeting. Annual fees for ordinary and student members shall be due and payable on September 1 of each year, or upon becoming a member. If membership is begun after March 31 of a given year, fees shall not be due again until September 1 of the following year. An invoice for fees owing, together with details of the Lecture Program for the year, will be mailed to non-institutional members each September.

\section{Proposed new NSIS by-law}

11. Membership and Annual Fees:

11a. Membership Period: The annual period of membership shall be from 1 September to 31 August of the following year. This "NSIS Year" approximates the academic year.

11b. Included in Membership Fees: Fees shall include payment for publications.

11c. Change of Fees: Any changes in the fees for ordinary, life, student, and/or institutional members shall be proposed by Council to the members, in writing, at least fourteen (14) days prior to the Annual General Meeting for approval by a majority vote of the members present at the Annual General Meeting.

11d. Due Dates: Annual fees for ordinary and student members shall be due and payable at the start of the NSIS Year, or upon becoming a member. Fees paid by new members joining after 9 months into the NSIS Year will cover membership for the following NSIS Year as well. 11e. Invoices and Receipts: An invoice for fees owing, together with details of the Lecture Program for the year, will be sent to noninstitutional members by the end of each NSIS Year. Upon payment, members shall be sent a receipt. These correspondences will be sent via e-mail, unless a member requests that the postal service be used. 11f. Membership Cards: Members will be given membership cards (credit-card/business-card sized) with their receipts for payment of dues. 


\section{THE NOMINATING COMMITTEE REPORT}

The Nominating Committee met on March $5^{\text {th }}$ and continued discussions by e-mail. During the process Jason Clyburne indicated that, because of other commitments, he did not think he would have the time needed to be President in 2015-2016. Patrick Ryall is willing to serve for a 2015-2016. Some councillors/officers indicated they were willing to continue, while others were not. Two people (Zoe Kirste \& Nicole LeBlanc) are willing to share the Publicity Officer responsibilities. We were not able to find someone willing to become the Membership Officer. The Committee recommends the following candidates for 2015/2016:

\section{Council}

President

Vice-President

Past-President

Secretary

Treasurer

Publicity Officer

Membership Officer

Librarian

Editor

Webmaster

Councillor

Councillor

Councillor

Councillor

Councillor
2014/2015

Patrick Ryall

Jason Clyburne

Thomas Rand

Kelly Abbott

Angelica Silva

Michelle Paon

Peter Wells

Suzuette Soomai

Hank Bird

Kevin Hewitt

Ron MacKay

Rick Singer

John Young
2015/2016

Patrick Ryall

Sherry Niven

Thomas Rand

Kelly Abbott

Angelica Silva

Zoe Kirste \&

Nicole LeBlanc

Michelle Paon

Peter Wells

Suzuette Soomai

Hank Bird

Victoria Turpin

Ron MacKay

Donald Stoltz

John Young 
